\title{
Water masses distribution offshore the Sabrina Coast (East Antarctica)
}

\author{
Manuel Bensi ${ }^{1}$, Vedrana Kovačević ${ }^{1}$, Federica Donda ${ }^{1}$, Philip Edward O’Brien ${ }^{2}$, Linda Armbrecht ${ }^{3}$, and \\ Leanne Kay Armand ${ }^{4}, \boldsymbol{t}$ \\ ${ }^{1}$ National Institute of Oceanography and Applied Geophysics (OGS), Trieste, 34010, Italy \\ ${ }^{2}$ Department of Environmental Sciences, Macquarie University, Sydney, Australia \\ ${ }^{3}$ Institute for Marine and Antarctic Studies, University of Tasmania, Battery Point, TAS 7004, Australia \\ ${ }^{4}$ Research School of Earth Sciences, Australian National University, Canberra, Australia

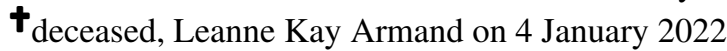

Correspondence: Manuel Bensi (mbensi@inogs.it)

Received: 21 July 2021 - Discussion started: 26 July 2021

Revised: 18 November 2021 - Accepted: 25 November 2021 - Published: 12 January 2022

\begin{abstract}
Current glacier melt rates in West Antarctica substantially exceed those around the East Antarctic margin. The exception is Wilkes Land, where for example Totten Glacier underwent significant retreat between 2000 and 2012, underlining its sensitivity to climate change. This process is strongly influenced by ocean dynamics, which in turn changes in accordance with the evolution of the ice caps. Here, we present new oceanographic data (temperature, salinity, and dissolved oxygen) collected during austral summer 2017 offshore the Sabrina Coast (East Antarctica) from the continental shelf break to ca $3000 \mathrm{~m}$ depth. This area is characterized by very few oceanographic in situ observations.

The main water masses of the study area, identified by analysing thermohaline properties, are the Antarctic Surface Water with potential temperature $\theta>-1.5^{\circ} \mathrm{C}$ and salinity $S<34.2\left(\sigma_{\theta}<27.55 \mathrm{~kg} \mathrm{~m}^{-3}\right)$, the Winter Water with $-1.92<\theta<-1.75^{\circ} \mathrm{C}$ and $34.0<S<34.5$ (potential density, $27.55<\sigma_{\theta}<27.7 \mathrm{~kg} \mathrm{~m}^{-3}$ ), the modified Circumpolar Deep Water with $\theta>0{ }^{\circ} \mathrm{C}$ and $S>34.5\left(\sigma_{\theta}>27.7 \mathrm{~kg} \mathrm{~m}^{-3}\right)$, and Antarctic Bottom Water with $-0.50<\theta<0{ }^{\circ} \mathrm{C}$ and $34.63<S<34.67\left(27.83<\sigma_{\theta}<27.85\right.$; neutral density $\left.\gamma^{\mathrm{n}}>28.30 \mathrm{~kg} \mathrm{~m}^{-3}\right)$. The latter is a mixture of dense waters from the Ross Sea and Adélie Land continental shelves. Such waters are influenced by the mixing processes they undergo as they move westward along the Antarctic margin, also interacting with the warmer Circumpolar Deep Water.

The spatial distribution of water masses offshore the Sabrina Coast also appears to be strongly linked with the complex morpho-bathymetry of the slope and rise area, supporting the hypothesis that downslope processes contribute to shaping the architecture of the distal portion of the continental margin.
\end{abstract}

Oceanographic data presented here can be downloaded from https://doi.org/10.25919/yyex-t381 (CSIRO; Van Graas, 2021).

\section{In memory of Prof. Leanne Kay Armand}

\section{Introduction}

Polar regions are key components of Earth's climate system and are particularly sensitive to ongoing climate change effects induced by anthropogenic pressures. It has been esti- mated that the full melting of all Antarctic ice has a sea level equivalent (SLE) of $\sim 58 \mathrm{~m}$ (Fretwell et al., 2013).

Understanding Earth's climate processes as well as their future projections depends on the constant collection and interpretation of long-term scientific data and palaeoclimatic records. Therefore, studying long-term records from polar regions is key (e.g. Masson-Delmotte et al., 2013) to have 
a more complete understanding of the region's past climate variability (e.g. Escutia et al., 2019). Within this frame, quantifying sea-level rise associated with global warming is crucial, and the accuracy of such quantifications ultimately depends on our knowledge of the response of polar regions to global warming. In fact, there is still significant uncertainty in estimates around sea-level rise, as Church et al. (2013) reported in the Intergovernmental Panel on Climate Change (IPCC) AR5 Sea Level Chapter. They delineate that significant challenges remain in understanding and predicting processes related to the dynamic response of Antarctic marineterminal glaciers and marine sectors. The Antarctic ice sheet response to current climate forcing can be elucidated by examining how the ice sheet had behaved in response to similar climate forcings in the past. In spite of the significant effort in putting the estimates together, the IPCC report expresses only medium confidence in estimating the contribution of Antarctic ice melt to sea levels during the last major warm episode, e.g. the Last Interglacial period, ca 129 to $116 \mathrm{kyr}$ ago (Masson-Delmotte et al., 2013).

Marine processes change in accordance with the evolution of the ice caps and vice versa, especially in those areas where glaciers are grounded below sea level. This condition occurs not only in West Antarctica, but also in several portions of East Antarctica (e.g. Adelie Land; Rignot et al., 2011), including the Sabrina Coast. Here, the Totten Glacier, the downstream end of the vast Aurora subglacial basin, is largely grounded below sea level and hence susceptible to rapid ocean-driven ice sheet basal melting (Pritchard et al., 2009; Roberts et al., 2011; Young et al., 2011; Rignot et al., 2013; Aitken et al., 2016; Hirano et al., 2021). Totten Glacier is, indeed, exposed to temperatures up to $3^{\circ} \mathrm{C}$ above the ice shelves' melting point (Rintoul et al., 2016). The Aurora subglacial basin today also hosts an active subglacial hydrological system that drains basal meltwater to the ocean (Wright et al., 2012).

According to Silvano et al. (2018), while relatively warm waters $\left(>0^{\circ} \mathrm{C}\right)$ flood the continental shelves in West Antarctica driving rapid basal melt of ice shelves, the ice shelves in East Antarctica experience relatively low rates of basal melt because they are influenced by cooler waters $\left(<0^{\circ} \mathrm{C}\right)$. However, the Totten Glacier is an exception, since the melting rates of this glacier and of the nearby Moscow University ice shelf (MUIS) are among the fastest in the East Antarctic ice sheets (Khazendar et al., 2013; Li et al., 2015; Mohajerani et al., 2018): the glacier draining into MUIS shows a $3 \mathrm{Gtyr}^{-1}$ loss in 1979-2003 and a $0.3 \mathrm{Gtyr}^{-1}$ gain in 2017, whereas Totten Glacier loss has increased through time from $5.7 \mathrm{Gtyr}^{-1}$ in $1979-2003$ to $7.3 \mathrm{Gtyr}^{-1}$ in $2003-$ 2017 (Rignot et al., 2019). These changes are enhanced by incursions of relatively warm modified Circumpolar Deep Water (mCDW) to the continental shelf and to the glacier grounding line, favoured by wind stress, local eddies, and bathymetric constraints (Rintoul et al., 2016; Silvano et al., 2016, 2017; Nitsche et al., 2017; Greene et al., 2017; Hi- rano et al., 2021). In fact, a deep and extensive pool of water with maximum temperature of $\sim 0.7^{\circ} \mathrm{C}$ has been identified at the outer continental shelf over a wide bathymetric depression at depths below 400-500 m (Nitsche et al., 2017). Ice loss can locally be also favoured by low levels of sea ice and Dense Shelf Water production in the Antarctic polynyas (Tamura et al., 2008), although there is still no clear evidence, surprisingly, of dense shelf water production in the Dalton Polynya, east of the Totten ice shelf (Silvano et al., 2018). Rignot et al. (2019) reported that Totten Glacier holds an ice volume that translates into a SLE of $3.85 \mathrm{~m}$. The $\mathrm{mCDW}$, being the major heat source on the Sabrina Coast continental shelf, is characterized by a temperature larger than $-0.4{ }^{\circ} \mathrm{C}$ and a salinity around $34.5-34.6$ (Silvano et al., 2017), and comprises the bottom layer of the water column. This appears to be different from other coastal areas of East Antarctica, where the bottom layer is usually occupied by colder and denser Shelf Water (Bindoff et al., 2000; Greenbaum et al., 2015). Studies of rapidly retreating outlet glaciers in the Amundsen Sea have shown a major role of the mCDW in transporting heat from the deep ocean onto the shelf, leading to enhanced glacier melting (Smith et al., 2011; Pritchard et al., 2012). This process has also been suggested as a possible cause for the rapid melting of Totten Glacier (e.g. Williams et al., 2011; Pritchard et al., 2012; Greene et al., 2017), but other mechanisms have been also suggested. Pritchard et al. (2012) invoked that changes in the circum-Antarctic wind field and its effects on upwelling around the continent cause the rapid basal melting of the Totten Glacier. Also, Khazendar et al. (2013) and Gwyther et al. (2014) have argued that this enhanced melting is the result of complex interactions between oceanic and shelf water masses at the base of the ice. In particular, Gwyther et al. (2014) suggested that the ice melting varies on seasonal and interannual timescales, with increased ice melt of the Totten Glacier coinciding with a reduced strength of the nearby Dalton Polynya. These studies rely heavily on satellite observations and bathymetry of the regions, e.g. the $1 \mathrm{~km}$ horizontal grid resolution obtained through the General Bathymetric Chart of the Oceans (GEBCO) used for oceanographic models (Gwyther et al., 2014). The GEBCO grid has two ship tracks in the critical 150 by $200 \mathrm{~km}$ area seaward of the Totten Glacier, meaning that most of the grid is a "best guess".

The Antarctic ice sheet nucleated in the higher elevations of the Gamburtsev Mountains and first reached the ocean near the Sabrina Coast and Prydz Bay (Huybrechts, 1993; DeConto and Pollard, 2003). Marine-terminating glaciers existed at the Sabrina Coast by the early-middle Eocene (ca. 56-41 Ma), implying the occurrence of ice caps before the emplacement of continental-scale ice sheets (Gulick et al., 2017). The first preserved evidence of grounded ice on the Sabrina Coast shelf is suggested to be late Eocene in age (ca. $38 \mathrm{Ma}$; Gulick et al., 2017). The climate evolution of the Wilkes Land margin, and thus of the Sabrina Coast, from the pre-glacial era to the present time comprises three main 
key periods: (i) pre-glacial conditions (Phase 1 reported in Donda et al., 2007); (ii) growth and development of a polythermal, highly dynamic ice sheet (Phases 2 and 3 in Donda et al., 2007), and (iii) transition to polar conditions (Phase 4 in Donda et al., 2007). This overall picture is well supported by several Antarctic and sub-Antarctic stratigraphic records, e.g. the Deep Sea Drilling Project Leg 28, Cape Roberts Project, Ocean Drilling Program Legs 119, 188, and 189 and International Ocean Discovery Program Leg 318 (Donda et al., 2020). Compared to other areas, the Sabrina Coast seismostratigraphy suggests that downslope processes contributed to shaping the distal margin architecture even during its latest development stages (i.e. Phase 4), when glacial meltwater-related fluxes were able to erode and deliver sediments to the rise area (Donda et al., 2020). The continental slope and rise of the Sabrina Coast reveal remarkable differences between the eastern and western areas, as also highlighted by the present-day bathymetry (Fig. 1). The western sector is shallower and characterized by the presence of two prominent NE-SW-trending ridges, separated by a low sinuosity narrow submarine canyon flanked with terraces. Here, one of these bathymetric highs favours the generation of a cyclonic gyre centred on $115^{\circ} \mathrm{E}$, just north of the shelf break (Wakatsuchi et al., 1994). Armand et al. (2018) described the eastern-facing slopes of the ridges (Fig. 1) as smooth seafloor with significant evidence of mass movement (e.g. slump scars and debris runout fields), while their westernfacing slopes are gullied terrain (with a gully depth range of up to $15 \mathrm{~m}$ ). In fact, the associated canyon is not receiving a high proportion of downslope turbidity currents, rather being fed by slumping on the adjacent ridge flanks ( $\mathrm{O}^{\prime}$ Brien et al., 2020). The eastern ridge was reported as having a lower slope than the western ridge, and being dominated by slump scars.

The eastern sector, instead, is characterized by a complex network of erosional channels and it is shaped by dendritic canyons, which meander and bend sharply to then join less sinuous main channels, the floors of which contain terraces and closed depressions (O'Brien et al., 2020). The ridges between canyons are clearly tied to their adjoining canyons and formed by westward advection of fine sediment lofted from turbidity currents and deposition of pelagic sediment (O'Brien et al., 2020). The western and the eastern areas are separated by a broad depression linked with one of the dendritic canyons near the lower slope. The upper slope consists of a smooth to gullied apron, downslope of which the canyon heads begin. The shelf break occurs at depths of $480-510 \mathrm{~m}$.

This paper aims at describing the thermohaline structures from the continental shelf break to about $3000 \mathrm{~m}$ depth identified in the offshore area along the Sabrina Coast, by analysing physical oceanographic data collected in 2017 during a multidisciplinary Antarctic expedition (see below).

\section{The oceanographic dataset: instrumentation and data processing}

Oceanographic data presented in this paper were collected offshore the Sabrina Coast, between 113 and $122^{\circ} \mathrm{E}$ and 66 and $64^{\circ} \mathrm{S}$ (Fig. 1) during the marine geoscience expedition "Interactions of the Totten Glacier with the Southern Ocean through multiple glacial cycles" (IN2017_V01) (see Armand et al., 2018). This expedition took place between 14 January and 7 March 2017 on board the Australian Marine National Facility (MNF) Research Vessel Investigator.

We take into account 31 conductivity-temperature-depth (CTD) vertical profiles (labelled 1-11, 13-23, 25-33) acquired in the study region (Fig. 2) using a Seabird SBE 9plus (pump-controlled) CTD and SBE 11plus V2 Deck Unit. The CTD was integrated with a SBE32 Carousel Water Sampler equipped with 36 Niskin bottles (OceanTest Equipment Inc. Florida; $12 \mathrm{~L}$ capacity each one, mounted on the rosette sampler), with additional sensor for measuring dissolved oxygen concentration (DO, SBE43), and an altimeter (PA500). The Commonwealth Scientific and Industrial Research Organisation (CSIRO) supplied calibration factors that were used to compute pressure, temperature, and conductivity/salinity values. Data were subjected to automated quality control (QC) to remove spikes and out-of-range values (see https://www.marine.csiro.au/data/reporting/get_file. cfm?eov_pub_id=1512, last access: 26 October 2021) while maintaining true data features. An additional filter was applied to the data to evaluate the median and standard deviation of the conductivity over a moving window. This has made it possible to detect extreme changes in the sensor values characteristic of the noise induced by spikes. The conductivity calibration was based on two deployment groupings, due to sensor changes during the voyage, and it was based upon the comparison between conductivity data obtained from CTD and water samples (104 of the total of 151 water samples taken during deployments). The final calibration for casts 1-13 from the secondary sensor had a standard deviation (SD) of $0.001 \mathrm{psu}$, while the final calibration for casts 14-33 from the secondary sensor had a SD of $0.002 \mathrm{psu}$. Water samples were also collected and used to compute new estimates of DO calibration coefficients, obtained by applying a linear regression. A single calibration group from each sensor was used with the associated SBE43 upcast data. The DO calibration had a SD of $0.85911 \mu \mathrm{M}$ with a good agreement between the sensor and bottle data. Based on the results obtained from the calibration procedure, the final dataset was obtained after $1 \mathrm{dbar}$ bin-averaged data from the secondary sensors (primary sensor for DO). Note that seven CTD profiles (casts 1, 2, 11, 13, 14, 15, and 18, see Fig. 2a) stopped before reaching the seafloor (between 200 and $700 \mathrm{~m}$, e.g. for testing the new sensor settings). Potential temperature $\left(\theta,{ }^{\circ} \mathrm{C}\right)$ and potential density anomaly $\left(\sigma_{\theta}, \mathrm{kg} \mathrm{m}^{-3}\right.$, referred to $\left.0 \mathrm{dbar}\right)$, and neutral density $\left(\gamma^{\mathrm{n}}, \mathrm{kg} \mathrm{m}^{-3}\right)$ were calculated using the toolbox TEOS-10 


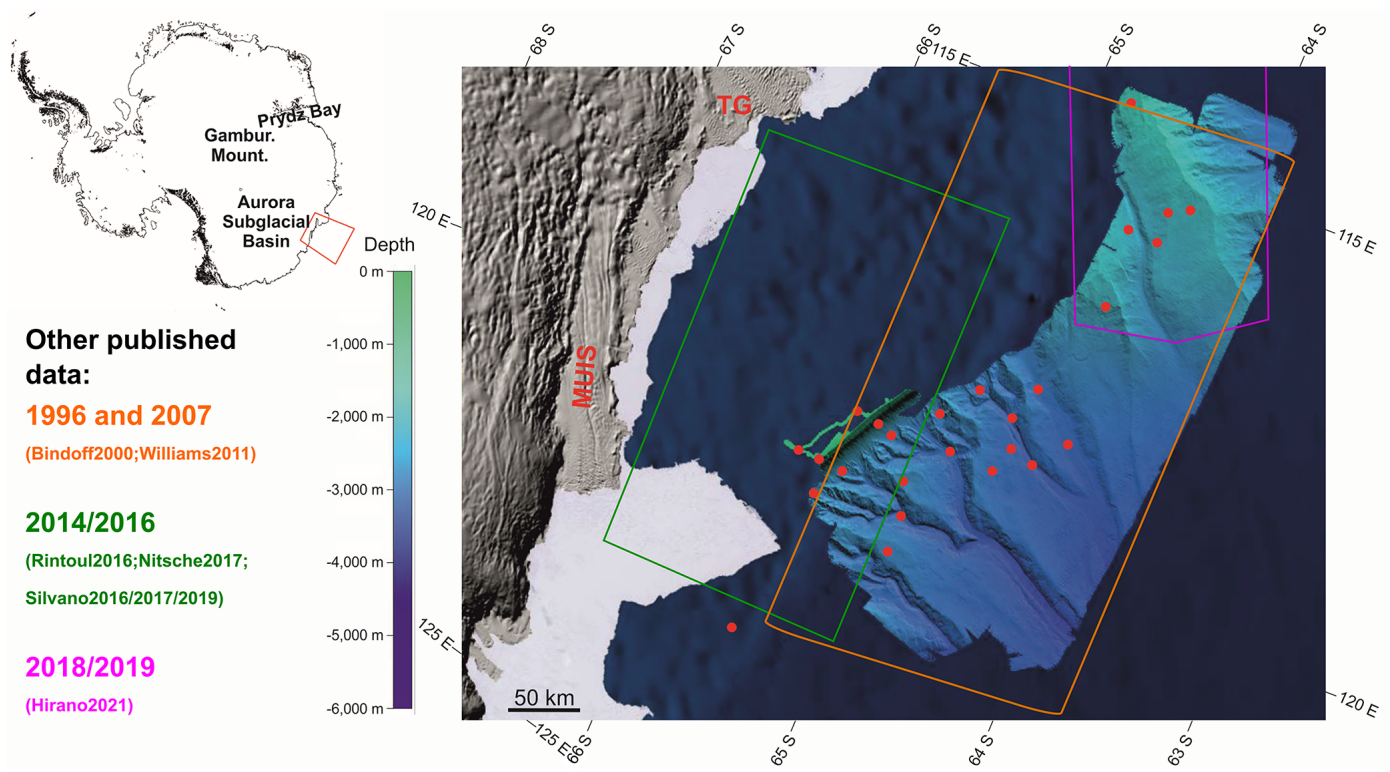

Figure 1. Sabrina Seafloor Survey area. Red dots indicate CTD casts collected during the IN2017_V01 cruise. Coloured polygons, instead, indicate areas where other already published hydrological data have been taken (reference years and related articles are indicated on the left). The high-resolution bathymetry is obtained from multibeam data acquired during the IN2017_V01 cruise (from O'Brien et al., 2020). On land, the terrain map comes from the Reference Elevation Model of Antarctica (REMA, Howat et al., 2019). The colourbar on the left refers to the high-resolution multibeam bathymetry.

(http://www.teos-10.org/software.htm, last access: 26 October 2021). We use $\sigma_{\theta}$ when considering the property distribution in the upper $500 \mathrm{~m}$, and where the specific $\sigma_{\theta}$ values determine and delimit specific water masses within the upper layers. However, the depth range of our study area is wide, and $\sigma_{\theta}$ errors augment with depth, therefore $\gamma^{\mathrm{n}}$ for the entire vertical range along vertical sections is used instead to depict the property distributions. Neutral density $\left(\gamma^{n}\right)$ is a function of temperature, salinity, pressure, latitude and longitude, where the reference level is slightly adjusted at each point to compensate for the nonlinearity of the equation of state; hence it can be considered a locally referenced potential density. Some figures were created using Ocean Data View (ODV; Schlitzer, 2021). More detailed information on instrumentation and quality control procedure is available at https://www.marine.csiro.au/data/trawler/ survey_details.cfm?survey=IN2017_V01 (last access: 26 October 2021).

Finally, satellite images (MODIS - Moderate-resolution Imaging Spectroradiometer, Corrected Reflectance imagery) were used to highlight both the evolution of sea ice within the period covered by the IN2017_V01 cruise and the extension of the Dalton Polynya (Fig. 2b and c), the open water surrounded by sea ice in the vicinity of Totten Glacier and MUIS. This is one of the largest Antarctic coastal polynya, with its wintertime average area of $3.7 \pm 2.0 \times$ $10^{3} \mathrm{~km}^{2}\left(6.5 \times 10^{3} \mathrm{~km}^{2}\right.$ at the time of the cruise; Fig. $2 \mathrm{~b}$ and $\mathrm{c}$ ), extending in the prevalent downwind direction (see e.g. Arroyo et al., 2019). Satellite images used in this work are freely available from the NASA Worldview application (https://worldview.earthdata.nasa.gov), part of the NASA Earth Observing System Data. The spatial imagery resolution is $250 \mathrm{~m}$, and the temporal resolution is daily.

\section{Thermohaline patterns in the study region}

\subsection{Typical water masses}

CTD casts are distributed over the continental slope and rise, offshore the area delimited by Totten Glacier and MUIS (Fig. 2). The main water masses are identified by analysing their $\theta-S$ (and DO) properties (Fig. 3) and classified according to Silvano et al. (2017, 2020). They are Antarctic Surface Water (AASW) with $\theta>-1.5^{\circ} \mathrm{C}$ and $S<34.2$ $\left(\sigma_{\theta}<27.55\right)$, Winter Water (WW) with $-1.92^{\circ} \mathrm{C}<\theta<$ $-1.75^{\circ} \mathrm{C}$ and $34.0<S<34.5\left(27.55<\sigma_{\theta}<27.7 \mathrm{~kg} \mathrm{~m}^{-3}\right)$, and mCDW, with $\theta>0{ }^{\circ} \mathrm{C}$ and $S>34.5\left(\sigma_{\theta}>27.7 \mathrm{~kg} \mathrm{~m}^{-3}\right)$. The AASW and WW are the most ventilated and therefore have the highest dissolved oxygen values. Acquired data do not reveal the presence of water with characteristics either of Ice Shelf Water (ISW, $\theta<-1.92{ }^{\circ} \mathrm{C}, S<34.5$, $27.55<\sigma_{\theta}<27.7 \mathrm{~kg} \mathrm{~m}^{-3}$ ) or Dense Shelf Water (DSW, $\theta<-1.92{ }^{\circ} \mathrm{C}, S>34.5, \sigma_{\theta}>27.7 \mathrm{~kg} \mathrm{~m}^{-3}$ ). In particular, the former is found close to the two ice shelves, and the latter forms within the polynyas, because of the intense cooling and brine rejection processes that can take place there. AASW comprises a wide range of both temperature and salinity. It is warm due to summer heating, and 

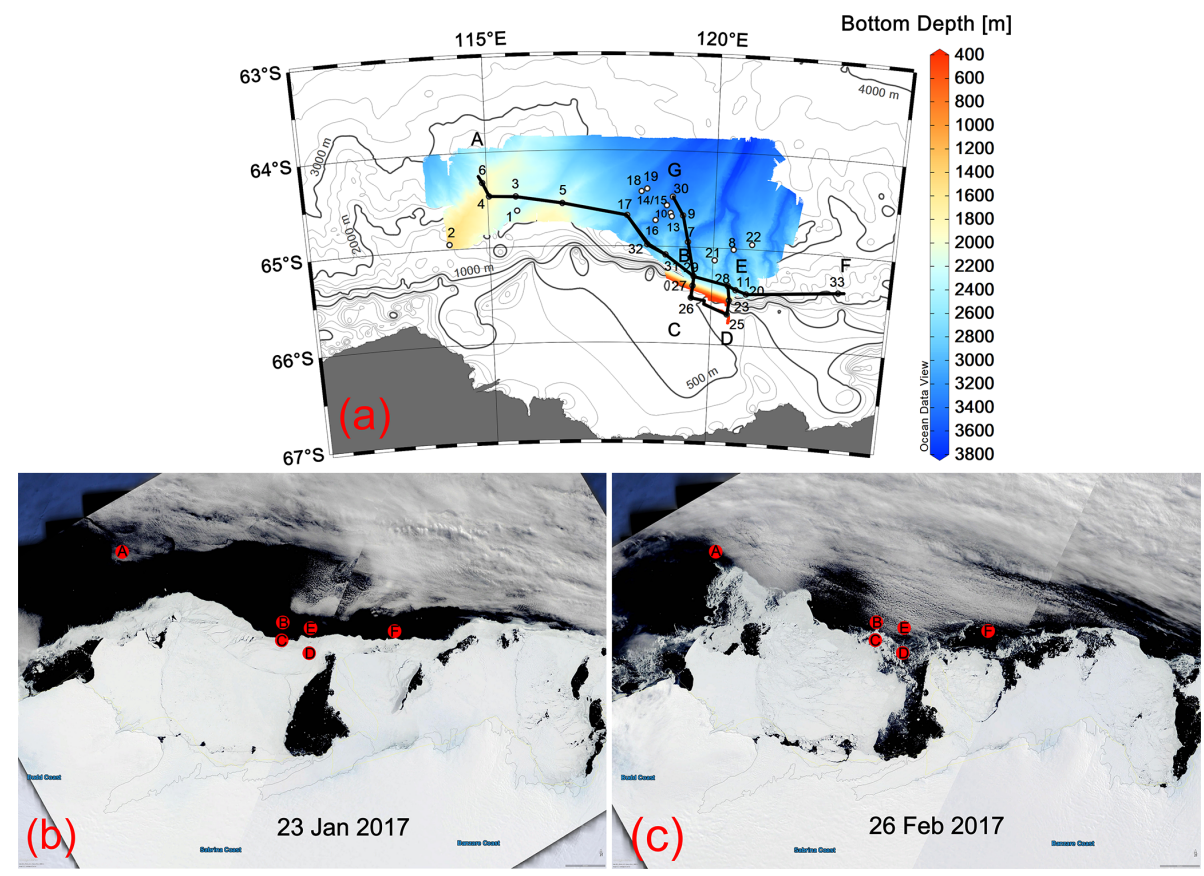

Figure 2. CTD stations map and colour-coded high-resolution bathymetry collected during the IN2017_V01 cruise (from O'Brien et al., 2020), superimposed over the International Bathymetric Chart of the Southern Ocean (contour lines). Positions A, B, C, D, E, F, and G denote along-slope and cross-slope transects (a). The same positions A-F (red dots) along the ice edge are superimposed on satellite images (MODIS Corrected Reflectance imagery freely available from https://worldview.earthdata.nasa.gov/, last access: 15 July 2021 ) taken on 23 January (b) and 26 February 2017 (c), which show the sea ice extension in the study region at the beginning and at the end of the IN2017_V01 cruise.

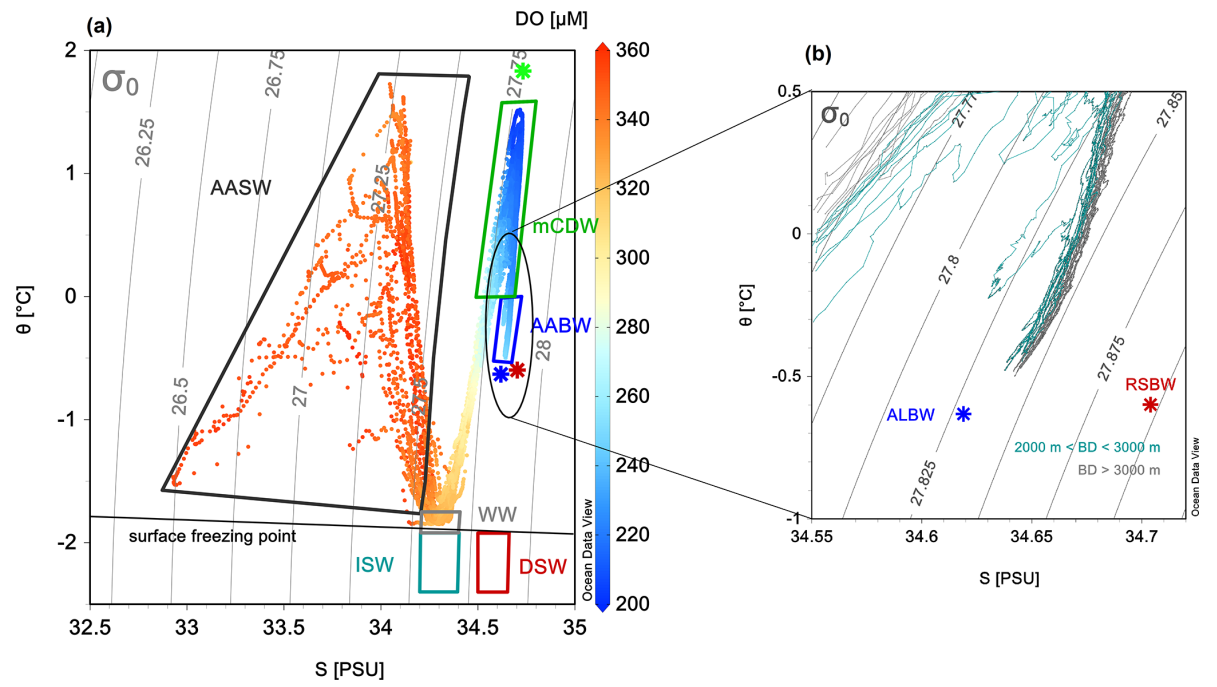

Figure 3. $\theta-S$ diagram (a) with colours referring to dissolved oxygen concentration (colourbar on the right). Characterization of the principal water masses according to Silvano et al. (2017, 2020): AASW - Antarctic Surface Water, WW - Winter Water, mCDW - modified Circumpolar Deep Water, AABW - Antarctic Bottom Water (with properties captured at $150^{\circ} \mathrm{E}$ ), ISW - Ice Shelf Water and DSW - Dense Shelf Water. Zoom of the $\theta-S$ diagram (b) into the deepest layers where bottom depths (BDs) are larger than $2000 \mathrm{~m}$. Endmembers of RSBW - Ross Sea Bottom Water (red asterisk), ALBW - Adélie Land Bottom Water (blue), and CDW (green) are indicated according to Thomas et al. (2020). 
(a)

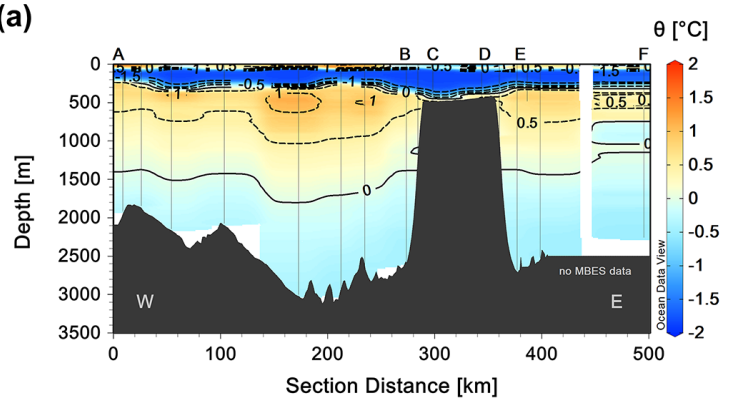

(c)

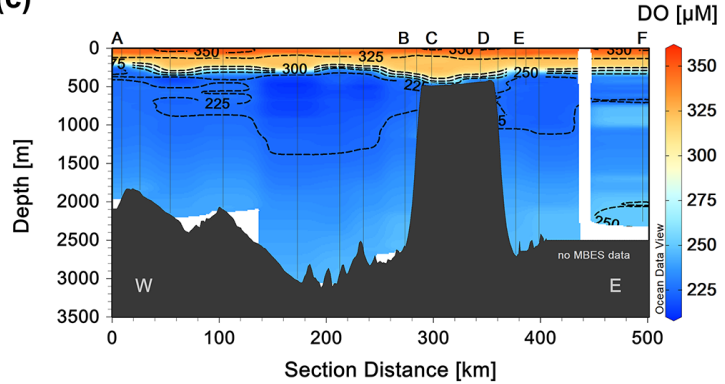

(b)

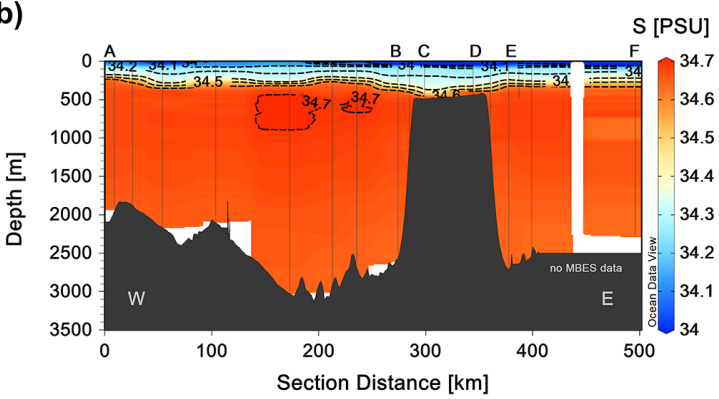

(d)

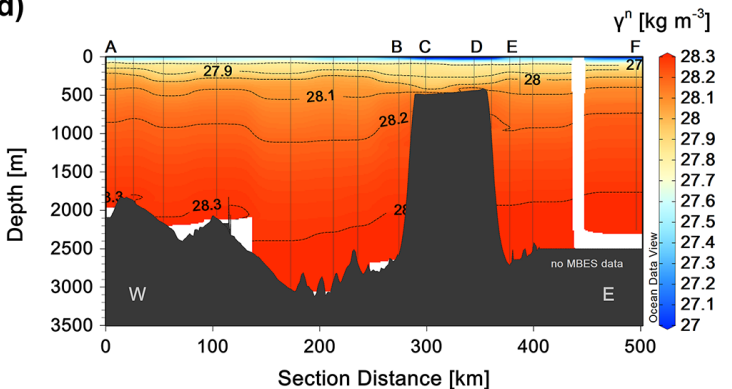

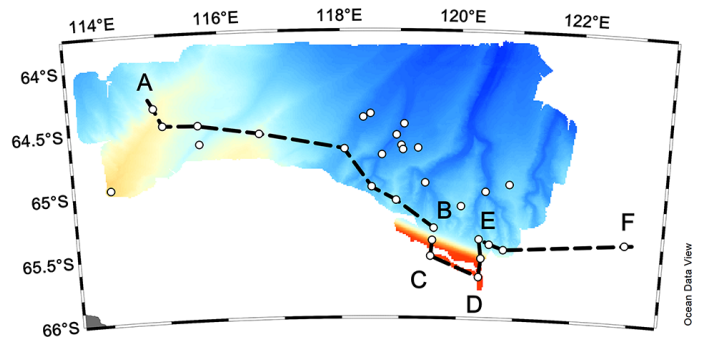

Figure 4. Along-slope transect (A-B, C-D, E-F) against distance, with two across-slope segments B-C and D-E. Vertical sections of $\theta$ (a), $S(\mathbf{b})$, DO concentration (c), and neutral density $\gamma^{\mathrm{n}}(\mathbf{d})$ over the entire depth range. See the insert map for the location of the transect.

fresh due mainly to sea ice melting. The WW occupies a homogeneous layer of the water column formed as a result of convection on the shelf during the previous winter. The $\mathrm{mCDW}$ is a relatively warm and salty water mass that can access the outer continental shelf through a section of the shelf break over $500 \mathrm{~m}$ depth (Nitsche et al., 2017), reaching the ice shelf cavity through a recently discovered oceanic entry route (Greenbaum et al., 2015) and causing ice melt. The thermohaline properties associated with the densest waters are attributed to the Antarctic Bottom Water (AABW, with $-0.50<\theta<0{ }^{\circ} \mathrm{C}, 34.63<S<$ $34.67,27.83<\sigma_{\theta}<27.85 \mathrm{~kg} \mathrm{~m}^{-3}$, and $\gamma^{\mathrm{n}}>28.30 \mathrm{~kg} \mathrm{~m}^{-3}$ ). The AABW in this part of the Australian Antarctic Basin (AAB) is a mixture of the local and remote dense waters, namely the Adélie Land Bottom Water (ALBW) and Ross Sea Bottom Water (RSBW, see e.g. Silvano et al., 2020), both of which have distinct characteristics in their source regions (Thomas et al., 2020). The most recent typical $\theta-S$ average values encountered during 2018 in the $\mathrm{AAB}$ were $-0.599^{\circ} \mathrm{C} / 34.704$ for the RSBW and $-0.632^{\circ} \mathrm{C} / 34.619$ for the ALBW (Thomas et al., 2020). We argue that these endmember values are representative also of the conditions encountered in 2017. However, thermohaline properties reported for the AABW in 2017 in our study area (Fig. 3) were slightly higher $\left(\sim+0.10^{\circ} \mathrm{C}\right.$ and +0.05 for $\theta$ and $S$, respectively) than those that referred to the mentioned endmembers, reflecting the mixing process that bottom waters experience as they move westwards along the Antarctic margin far from their area of origin.

\subsection{Spatial distribution of the hydrographic properties}

To describe thermohaline properties in the study area and in proximity of the sea ice edge, we consider a zonal section (W-E) running almost parallel to the continental slope, extending from station 6 to station 25 (Fig. 4), combined with two short cross-slope segments in correspondence of the shelf break. An overall distribution of $\theta, S$, DO concentration, and neutral density indicates well-defined layers of AASW, WW, and mCDW. AASW is situated in the relatively 
(a)

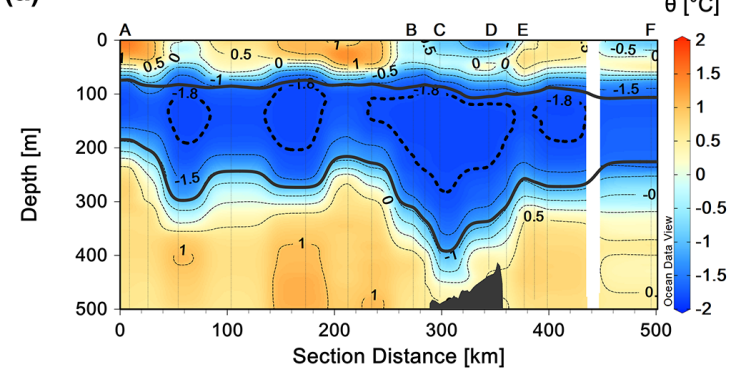

(c)

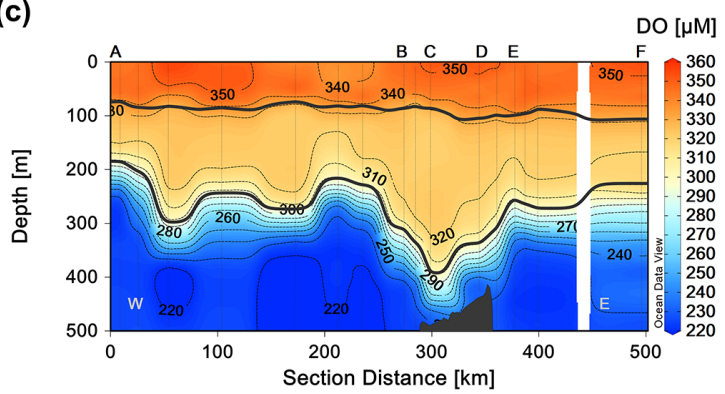

(b)

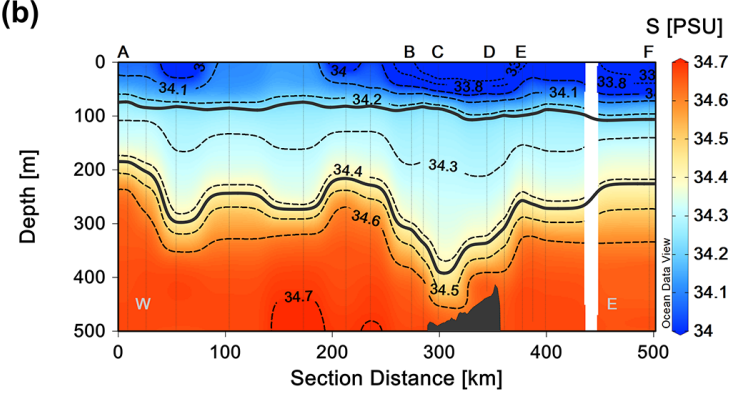

(d)

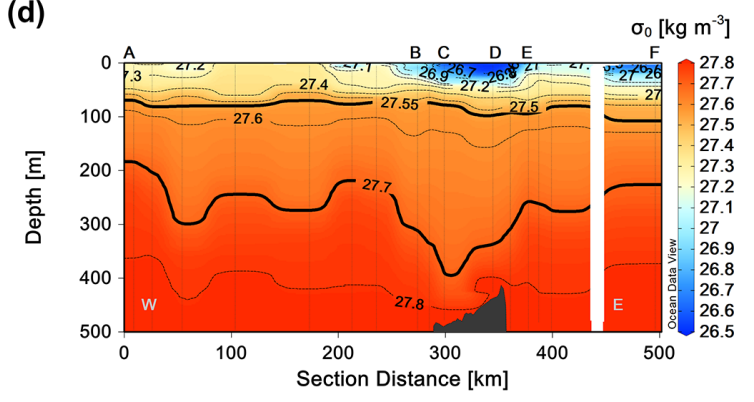

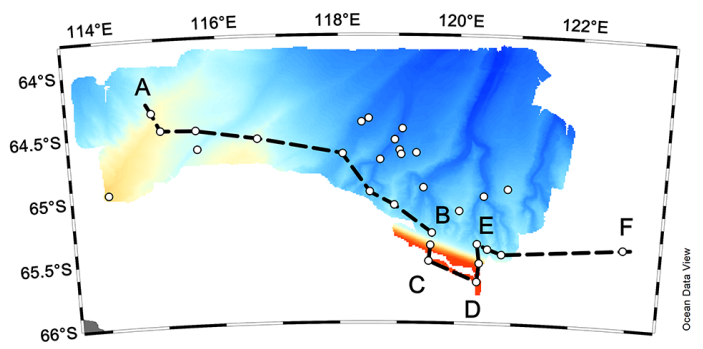

Figure 5. Along-slope transect (A-B, C-D, E-F) against distance, with two across-slope segments B-C and D-E. Vertical sections of $\theta$ (a), $S(\mathbf{b})$, DO concentration (c), and $\sigma_{\theta}$ referring to $0 \mathrm{dbar}$ (d) in the upper $500 \mathrm{~m}$. Thick black lines in each panel indicate isopycnals 27.55 and $27.70 \mathrm{~kg} \mathrm{~m}^{-3}$, delimiting the layer occupied by WW (defined according to Silvano et al., 2017). See the insert map for the location of the transect.

shallow surface layer (0-50 m depth), but with a wide range of temperature and salinity. Cold, fresh, and relatively uniform in temperature and salinity, WW lies beneath within the upper $400 \mathrm{~m}$ with larger thickness over the slope and shelf break. Beneath $400 \mathrm{~m}$ depth, warm and salty mCDW occupies the largest portion of the water column, decreasing its temperature and salinity approaching the shelf break (between positions $\mathrm{C}$ and $\mathrm{D}$ ). There, it spreads over the continental shelf.

A closer look into the upper $500 \mathrm{~m}$ layer reveals a welloxygenated AASW (Fig. 5). Its temperature and salinity decrease at the shelf break (area B-C-D-E), probably due to the influence of cold and fresh ice melting water coming from the continental shelf (see Fig. $2 b$ and $c$ for the evolution of sea ice in January-February 2017). The portion of the water column occupied by WW, approximately between 50 and $400 \mathrm{~m}$ depth, is cold $\left(-1.5<\theta<-0.5^{\circ} \mathrm{C}\right)$, relatively fresh $(S<34.45)$, and well oxygenated (DO $>300 \mu \mathrm{M})$. The largest thickness of WW corresponds to the area approaching the continental shelf break (B-C-D-E, water depths between 400 and $500 \mathrm{~m}$ ), and it is typically associated with the downward tilting of density surfaces at the fresh shelf fronts, as described by Thompson et al. (2018).

From $500 \mathrm{~m}$ down to the continental slope and rise area, to depths greater than $3000 \mathrm{~m}$, both temperature and salinity progressively decrease. Below $1500 \mathrm{~m}$, in particular, cold waters have temperatures ranging from 0 to almost $-0.5^{\circ} \mathrm{C}$ near the bottom (Fig. 6). The lowest temperature values $\left(-0.479^{\circ} \mathrm{C}\right)$ are recorded in the easternmost part of the zonal transect, along with relatively low salinity (38.638-38.640), and high oxygen (up to $248-250 \mu \mathrm{M}$ ) especially in the easternmost part of the section. The densest waters lie in the depressions/canyons/troughs between 118 and $119^{\circ} \mathrm{E}$ (neutral density $28.325 \mathrm{~kg} \mathrm{~m}^{-3}$ ). Despite the relatively large distance among CTD stations, the sections of the thermohaline properties and dissolved oxygen concentration reveal that, close to the bottom, in correspondence of the canyons and rugged bottom morphology (i.e. near positions B and E in Fig. 6) 
(a)

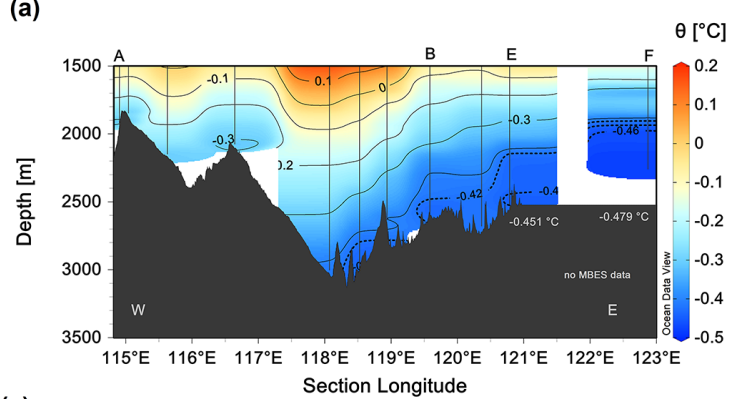

(c)

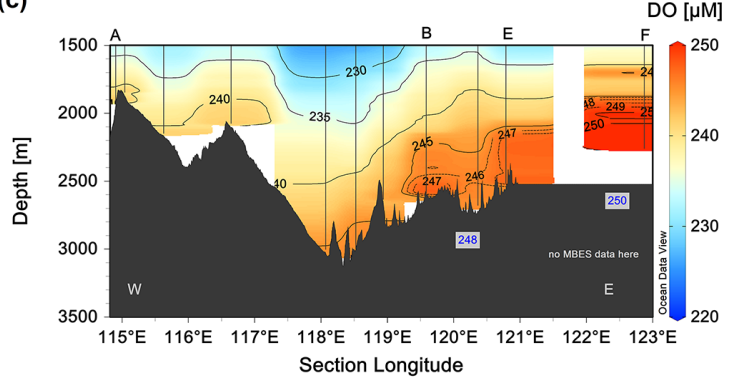

(b)

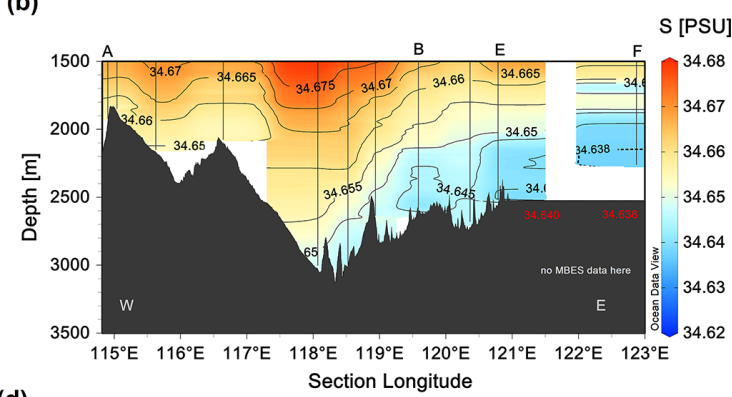

(d)

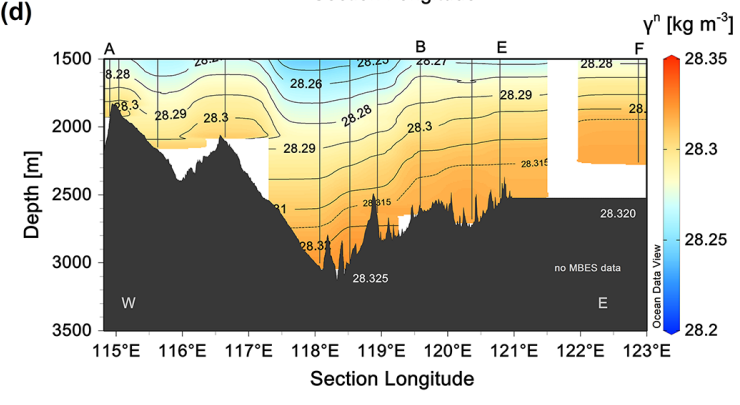

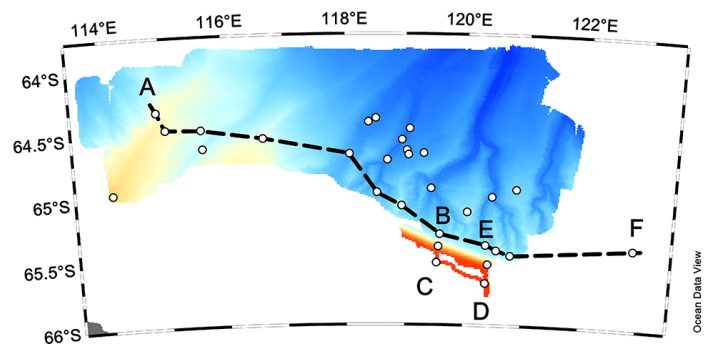

Figure 6. Along-slope transect A-B-E-F against the geographical longitude. Vertical sections of $\theta$ (a), $S$ (b), DO concentration (c), and neutral density $\gamma^{\mathrm{n}}(\mathbf{d})$ in the deep depth range (1500 m-bottom). The isoline steps are chosen to make evident small changes of the hydrographic properties near the bottom where waters are the coldest, the freshest, the densest, as well as rich in dissolved oxygen content. See the insert map for the location of the transect.

there are signals of possible pathways of dense waters. The high resolution of the neutral density isolines makes it possible to detect how the isopycnals, and all other properties, follow the bottom morphology (Fig. 6).

Patches of the deep and dense waters have properties that can be attributed to those of AABW (Figs. 3 and 4), which here seems influenced by ALBW rather than RSBW. CTD profiles at the deepest stations, which are within the canyons, are slightly saltier (see Fig. 3b) possibly due to the mixing either with the mCDW or with modified RSBW. From our data there is no clear evidence about the contribution of dense waters originating from the continental shelf. However, these processes could occur only in favourable conditions, e.g. during austral winters. The possible spread of such water out of the continental shelf area could give origin to densitydriven flows that descend within canyons along the continental slope and could help shape the seafloor morphologies described by O'Brien et al. (2020).
To better identify the distribution of the water masses between the continental shelf and the off shelf area, we draw a S-N across-slope section. In fact, the transect $\mathrm{C}-\mathrm{B}-\mathrm{G}$ (see Fig. 7) illustrates a progressive thinning of the WW layer from the shelf break toward the open sea, associated with the Antarctic Slope Front that separates cold and fresh shelf waters from the warm and salty mCDW offshore (Thompson et al., 2018). Within the thick core layer of mCDW in the off shelf area, $\theta$ and $S$ reach their maximum and the DO content reaches its minimum between 64.6 and $64.8^{\circ} \mathrm{S}$. The layer occupied by mCDW progressively narrows in the opposite direction toward the shelf break, where it also becomes less warm and less salty. There, the mCDW tongue protrudes toward the shelf beneath the WW. On the continental slope, at approximately $1100 \mathrm{~m}$ depth, a slight temperature decrease appears (Fig. 7a). However, the coarse space resolution between CTD stations precludes defining its origin. The deep and near-bottom layers better illustrate how the isopycnals and associated thermohaline properties, along 
(a)

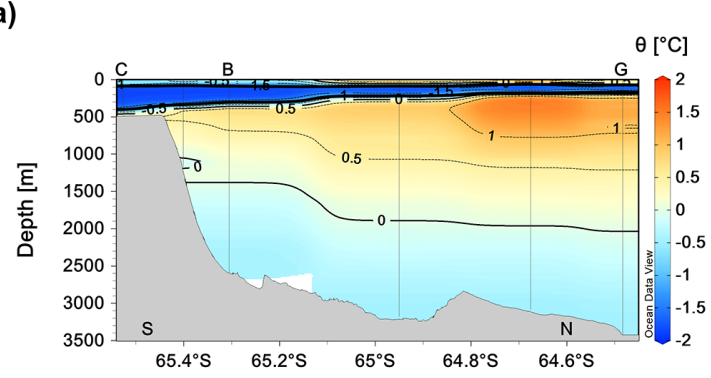

(c)

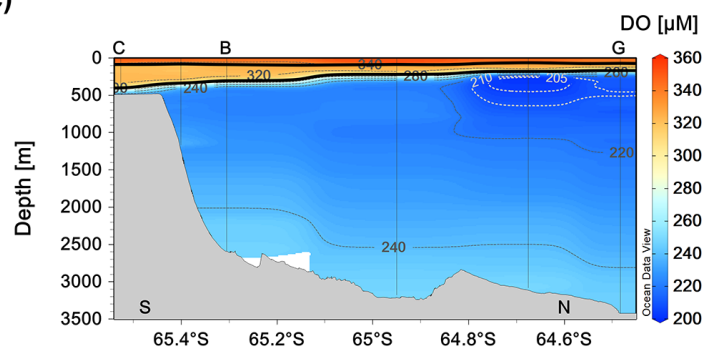

(b)

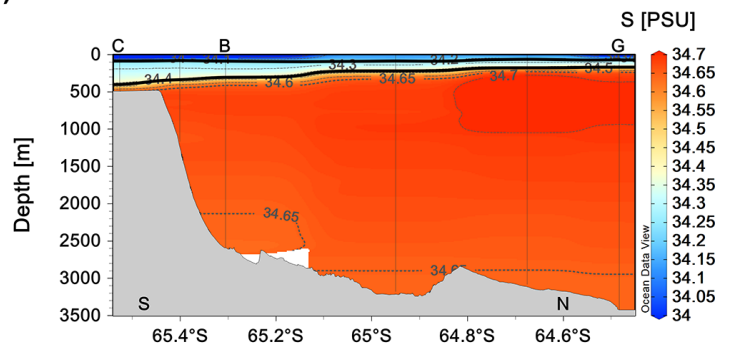

(d)

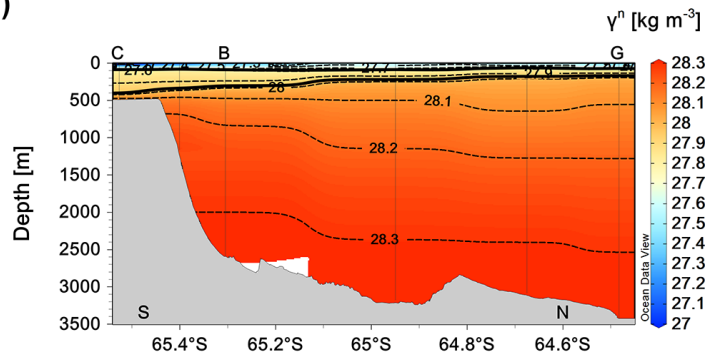

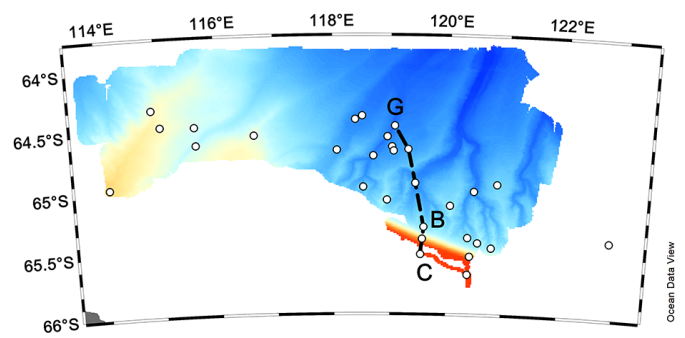

Figure 7. Across-slope transect C-B-G against the geographical latitude. Vertical sections of $\theta$ (a), $S$ (b), DO concentration (c), and neutral density (d) over the entire depth range. Isopycnals of 27.55 and $27.70 \mathrm{~kg} \mathrm{~m}^{-3}$ are shown in all panels (thick black lines), delimiting WW (according to Silvano et al., 2017). See the insert map for the location of the transect.

with the DO content, align with the morphology of the sea floor (Fig. 8). There, coherent changes in $\theta, S$, and DO point out at a cold, relatively fresh, and oxygenated bottom layer, approximately $400-500 \mathrm{~m}$ thick, leaning on the continental slope and rise. Its well-delimited characteristics fade away from $64.6^{\circ} \mathrm{S}$ northward.

The horizontal distribution of thermohaline properties near the surface (Fig. 9a, d, g, and j) in the study area shows how they change in the across-slope direction, while they are more homogeneous along the direction parallel to the continental margin. From the shelf area, cold, fresh, and oxygenated waters approach the shelf break, where, due to their relatively low density, they mix with other waters in the upper layer within the Antarctic Slope Front. The strongest signal from shelf waters is visible at about $120^{\circ} \mathrm{E}$ while fading in the northernmost portion offshore the study region, where higher values of $\theta$ and $S$ (up to $2.0^{\circ} \mathrm{C}$ and 34.2, respectively) are observed at $15 \mathrm{~m}$ depth. The $450 \mathrm{~m}$ depth horizon (Fig. 9b, e, h, and k) is chosen to represent the core of the $\mathrm{mCDW}\left(\theta\right.$ values $\left.>0{ }^{\circ} \mathrm{C}\right)$ in the offshore area, within a layer that extends from about 300 down to $2000 \mathrm{~m}$ (Fig. 7). Here, $S$ reaches its maximum values and DO its minimum. In the region between 118 and $120^{\circ} \mathrm{E}$, the mCDW probably finds its favourable pathway to the continental shelf due to the bottom morphology. Approaching the shelf break, the mCDW mixes with other water masses originating locally or transported by the Antarctic Slope Current westward along the continental margin. Close to the bottom (Fig. 9c, f, i, and l), maxima $\theta$ and $S$ with values of about $0.5^{\circ} \mathrm{C}$ and 34.678 , respectively, are registered over the shelf break at the southernmost station 25 (at ca. $120^{\circ} \mathrm{E}, 420 \mathrm{~m}$ depth). These large near-bottom values reflect the $\mathrm{mCDW}$ impinging on the slope beneath the cold and fresh WW. Overall, in the westernmost part of the study area $\left(115-117^{\circ} \mathrm{E}\right)$ at depths around $2000 \mathrm{~m}$, the bottom layer is occupied by waters with $\theta$ around $-0.30^{\circ} \mathrm{C}$ and $S$ around 34.65-34.66, hence slightly warmer and saltier (and less dense) than bottom waters found at similar depths in the central and eastern sectors (Fig. 9c and f). Yet, the fact that bottom waters in the western sector, which is generally shallower than the eastern one (Fig. 6), have lower DO values 
(a)

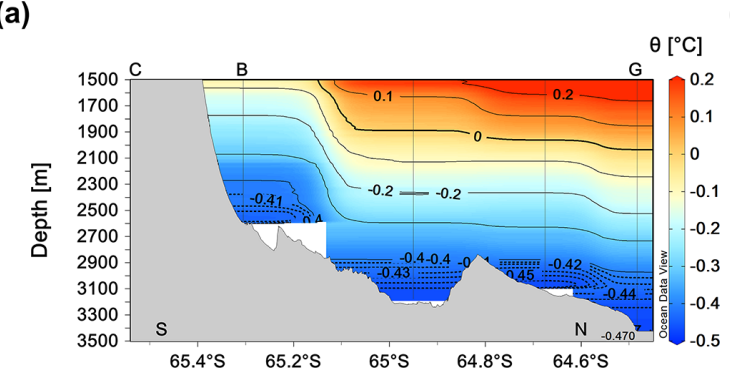

(c)

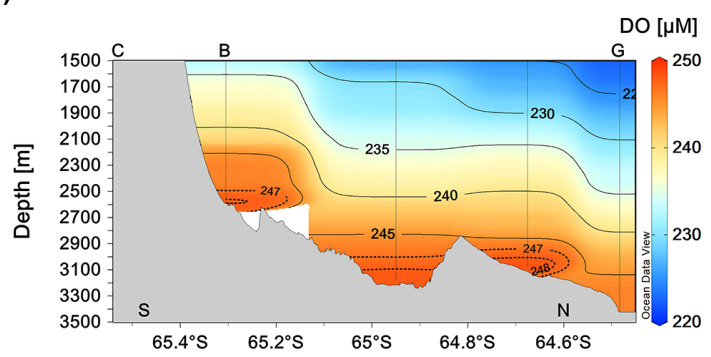

(b)

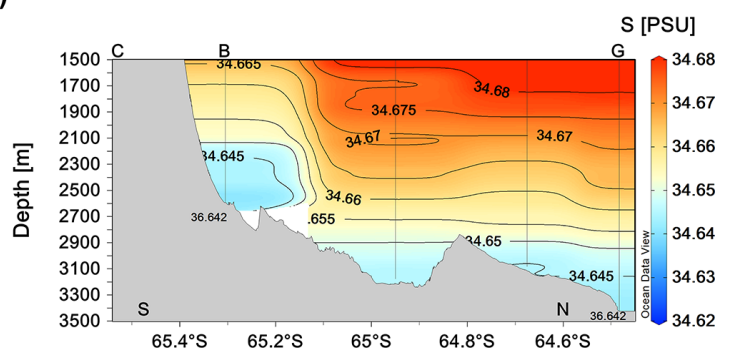

(d)

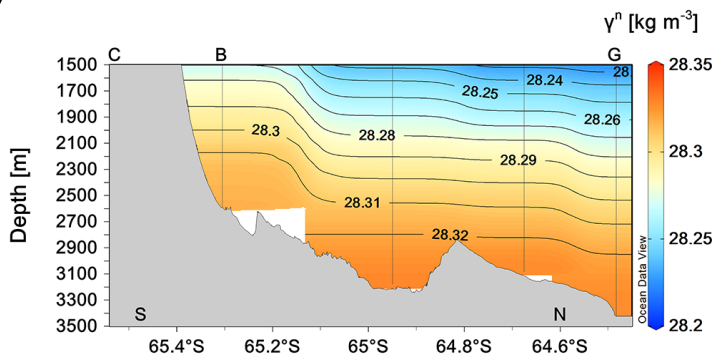

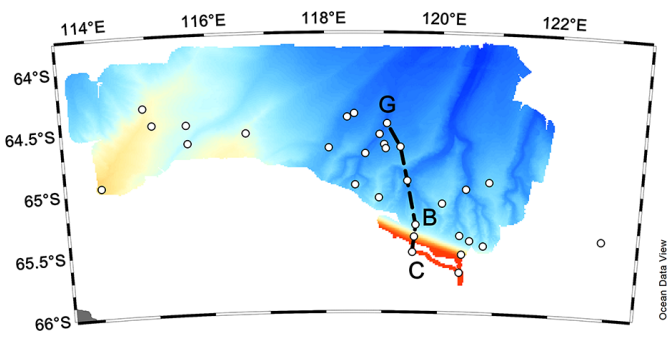

Figure 8. Same as Fig. 7 but with a zoom into the $1500 \mathrm{~m}$-bottom layer. The isoline steps are chosen to make evident small changes of the hydrographic properties near the bottom where waters are the coldest, the freshest, the densest, as well as rich in dissolved oxygen content. See the insert map for the location of the transect.

suggests that this area is also influenced by mCDW. Intrusions of mCDW onto the continental shelf, forced primarily by wind-driven upwelling (Greene et al., 2017; Silvano et al., 2019), can occur where the shelf break is deeper than $400 \mathrm{~m}$. Hence, $\mathrm{mCDW}$ can flow down the landward-sloping continental shelf, reaching the Totten Glacier grounding zone (Greenbaum et al., 2015; Nitsche et al., 2017; Silvano et al., 2017, 2019).

\section{Data availability}

All data used in this work are archived in the enduring CSIRO Data Access Portal (https://data.csiro.au, last access: 26 October 2021), and they can be downloaded from https://doi.org/10.25919/yyex-t381 (CSIRO and Van Graas, 2021). Metadata records are made publicly available at http://www.marlin.csiro.au, Van Graas and Dirita, 2021). Processed data and data products are, instead, publicly available through Data Trawler (http://www.marine. csiro.au/data/trawler/index.cfm, CSIRO National Collections and Marine Infrastructure (NCMI), 2021a) and the
MNF web data access tool (http://www.marine.csiro.au/data/ underway/, CSIRO National Collections and Marine Infrastructure (NCMI), 2021b).

\section{Summary and conclusions}

Here we present oceanographic data (temperature, salinity, density, dissolved oxygen) collected offshore the continental margin of the Sabrina Coast (East Antarctica) between 113 and $122^{\circ} \mathrm{E}$ and 66 and $64^{\circ} \mathrm{S}$, from the shelf edge to the continental rise (Figs. 1 and 2). The water masses, described mainly according to their $\theta / S$ properties, are influenced by the seasonal heating and freshening of the uppermost layers, and their spatial distribution appears to be linked to the complex morpho-bathymetric setting of the study area. At about 400-500 m depth, the mCDW approaches shelf break in the area between 118 and $120^{\circ} \mathrm{E}$, around $64.5^{\circ} \mathrm{S}$, in good agreement with the numerical simulation results by Silvano et al. (2019). Small variations of the thermohaline properties in the 400-500 $\mathrm{m}$ thick bottom layer in correspondence of the canyons revealed, instead, that there are signals of dense wa- 

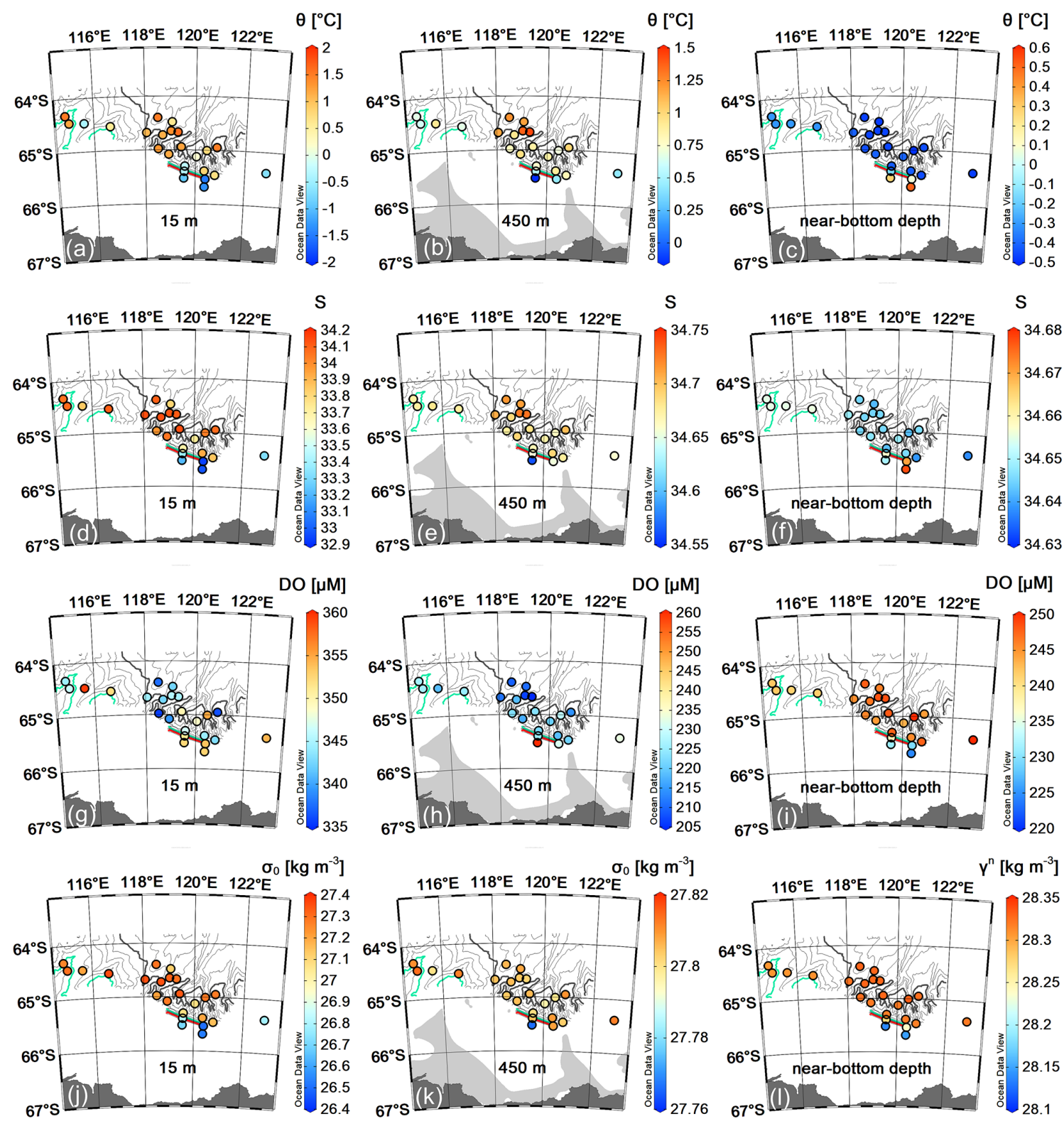

Figure 9. Near-surface ( $15 \mathrm{~m}$ depth), intermediate $(450 \mathrm{~m})$ and near-bottom $\theta(\mathbf{a}-\mathbf{c}), S(\mathbf{d}-\mathbf{f})$, DO content $(\mathbf{g}-\mathbf{i}), \sigma_{\theta}(\mathbf{j}, \mathbf{k})$ and neutral density $\gamma^{\mathrm{n}}$ (l). The background bathymetry consists of isobaths (thin black curves) every $200 \mathrm{~m}$ obtained from multibeam data acquired during the 2017 campaign; thick lines indicate isobaths at 1000 (red), 2000 (cyan), and $3000 \mathrm{~m}$ (grey).

ters with low $\theta$ and $S$ values $\left(-0.445^{\circ} \mathrm{C}\right.$ and $38.638-38.640$, respectively) and relatively high DO values $(240-250 \mu \mathrm{M})$. Densest waters, as shown in the $\theta-S$ plot (Fig. 3), have characteristics closer to typical ALBW than to RSBW. In general, mixing of these dense waters with the mCDW is not excluded. Data also reveal that bottom layers at stations with depths greater than $3000 \mathrm{~m}$ (i.e. inside canyons) are occupied by water slightly saltier than that found at depths between 2000 and $3000 \mathrm{~m}$, but with similar temperatures. However, even though from our data there is no clear evidence about the contribution of dense waters originating from the conti- nental shelf, we cannot exclude that during winter and spring seasons, occasional dense water plumes may descend and fill the deep layer, possibly mixing with the AABW. This hypothesis would support the fact that density-driven currents along the steep slopes in the eastern portion of this region could contribute, on the one hand, to shaping the presentday, deeply incised canyons (Donda et al., 2020) and, on the other hand, to redistributing the different water masses (i.e. AASW, WW, and mCDW) off the continental shelf beyond the shelf edge, favouring their mixing. Our data also reveal that in the western sector of the study area (west of $118^{\circ} \mathrm{E}$ ) 
the bottom layer appears to be occupied by waters that are slightly warmer and saltier, as well as less oxygenated, than those found in the central and easternmost sectors. This difference in the deep water properties of the two sectors (eastern and western) seems to be an effect generated by the particular morphology of the seabed, being the western sector shallower than the eastern one, and hence more easily influenced by mixing with the mCDW. In addition, ocean currents and associated processes (along-slope flow, eddies, internal waves and tides, downslope density-driven currents) that involve local water masses may be different in the two sectors. This implies that mCDW intrusions (Greene et al., 2017) and thus heat transport on the Sabrina Coast continental shelf could be favoured by a combined effect induced by winds, eddies, and bathymetric constraints (i.e. along slope canyons, Hirano et al., 2021).

The IN2017_V01 expedition was conducted during austral summer, when rapidly changing sea-ice conditions also influence the near-surface and upper layers. The complex interplay of processes along the continental shelf, slope, and rise in this area is certainly challenging, suggesting the importance of learning more about oceanographic dynamics during both winter and summer seasons. In particular, the possibility of acquiring high temporal resolution data, especially during the winter period (e.g. by using long-term in situ observatories), could help in the understanding of the oceanographic processes that have contributed to shape the distal margin architecture and have influenced the evolution of the ice sheet.

Author contributions. MB, VK, and FD conceived and wrote the article. MB and VK processed the data used to prepare the figures and performed the analyses. FD led the TYTAN project; LKA and PEO led the IN2017_V01 scientific cruise. LA contributed to collect experimental data and participated in writing the text. All authors contributed to the discussion and revision of the manuscript.

Competing interests. The contact author has declared that neither they nor their co-authors have any competing interests.

Disclaimer. Publisher's note: Copernicus Publications remains neutral with regard to jurisdictional claims in published maps and institutional affiliations.

Acknowledgements. We thank the Marine National Facility (https://ror.org/01mae9353, last access: 26 October 2021), the IN2017_V01 scientific party, led by the Leanne Kay Armand and Philip Edward O'Brien, MNF support staff and ASP crew members led by Captain Mike Watson for their help and support on board the RV Investigator. We also thank Andres Roubicek and Dave Watts (CSIRO NCMI, Information and Data Centre) for the assistance with data accessibility.
Financial support. This research was supported through funding from the Australian Government's Australian Antarctic Science Grant Program (AAS no. 4333) and the Australian Research Council's Discovery Projects funding scheme (DP170100557). We would like also to acknowledge the financial support of the Italian National Antarctic Research Program (Programma Nazionale di Ricerche in Antartide, PNRA) that funded the participation of the Italian team to the cruise through the project TYTAN (Totten Glacier dYnamics and Southern Ocean circulation impact on deposiTional processes since the mid-lAte CeNozoic, PNRA no. 2015/B2.02) led by Federica Donda.

Review statement. This paper was edited by Giuseppe M. R. Manzella and reviewed by two anonymous referees.

\section{References}

Armand, L. K., O’Brien, P. E., and On-board Scientific Party: Interactions of the Totten Glacier with the Southern Ocean through multiple glacial cycles (IN2017_V01), Post-survey report, Research School of Earth Sciences, Australian National University, Canberra, https://doi.org/10.4225/13/5acea64c48693, 2018.

Arroyo, M. C., Shadwick, E. H., and Tilbrook, B.: Summer Carbonate Chemistry in the Dalton Polynya, East Antarctica, J. Gwophys. Res.-Oceans, 124, 5634-5653, https://doi.org/10.1029/2018JC014882, 2019.

Aytken, A. R. A., Roberts, J. L., van Ommen, T. D., Young, D. A., Golledge, N. R., Greenbaum, J. S., Blankenship, D. D., and Siegert, M. J.: Repeated large-scale retreat and advance of Totten Glacier indicated by inland bed erosion, Nature, 533, 385-389, https://doi.org/10.1038/nature17447, 2016.

Bindoff, N. L., Rosenberg, M. A., and Warner, M. J.: On the circulation and water masses over the Antarctic continental slope and rise between 80 and $150^{\circ}$ E, Deep-Sea Res. Pt. II, 47, 22992326, https://doi.org/10.1016/S0967-0645(00)00038-2, 2000.

Church, J. A., Clark, P. U., Cazenave, A., Gregory, J. M., Jevrejeva, S., Levermann, A., Merrifield, M. A., Milne, G. A., Nerem, R. S., Nunn, P. D., Payne, A. J., Pfeffer, W. T., Stammer, D., and Unnikrishnan, A. S.: Sea Level Change, in: Climate Change 2013: The Physical Science Basis. Contribution of Working Group I to the Fifth Assessment Report of the Intergovernmental Panel on Climate Change, edited by: Stocker, T. F., Qin, D., Plattner, G.K., Tignor, M., Allen, S. K., Boschung, J., Nauels, A., Xia, Y., Bex, V., and Midgley, P. M., Cambridge University Press, Cambridge, United Kingdom and New York, NY, USA, 2013.

CSIRO and Van Graas, S.: RV Investigator Voyage IN2017_V01 CTD Data. v1, CSIRO [data set], https://doi.org/10.25919/yyext381, 2021.

CSIRO National Collections and Marine Infrastructure (NCMI): Data Trawler, available at: http://www.marine.csiro.au/data/ trawler/index.cfm, last access: 26 October 2021a.

CSIRO National Collections and Marine Infrastructure (NCMI): Near Real-time Underway Data, available at: http://www.marine. csiro.au/data/underway/, last access: 26 October 2021 b.

De Conto, R. M. and Pollard, D.: Rapid Cenozoic glaciation of Antarctica induced by declining atmospheric $\mathrm{CO}_{2}$, Nature, 421, 245-249, https://doi.org/10.1038/nature01290, 2003. 
Donda, F., Brancolini, G., O'Brien, P. E., De Santis, L., and Escutia, C.: Sedimentary processes in the Wilkes Land margin: a record of Cenozoic East Antarctic Ice Sheet evolution, J. Geol. Soc. London, 164, 243-256, https://doi.org/10.1144/0016-76492004-159, 2007.

Donda, F., Leitchenkov, G., Brancolini, G., Romeo, R., De Santis, L., Escutia, C., O'Brien, P. E., Armand, L., Caburlotto, A., and Cotterle, D: The influence of the Totten Glacier on the Late Cenozoic sedimentary record, Antarct. Sci., 32, 288-300, https://doi.org/10.1017/S0954102020000188, 2020.

Escutia, C., DeConto, R. M., Dunbar, R., De Santis, L., Shevenell, A., and Naish, T.: Keeping an eye on Antarctic Ice Sheet stability, Oceanography, 32, 32-46, https://doi.org/10.5670/oceanog.2019.117, 2019.

Fretwell, P., Pritchard, H. D., Vaughan, D. G., Bamber, J. L., Barrand, N. E., Bell, R., Bianchi, C., Bingham, R. G., Blankenship, D. D., Casassa, G., Catania, G., Callens, D., Conway, H., Cook, A. J., Corr, H. F. J., Damaske, D., Damm, V., Ferraccioli, F., Forsberg, R., Fujita, S., Gim, Y., Gogineni, P., Griggs, J. A., Hindmarsh, R. C. A., Holmlund, P., Holt, J. W., Jacobel, R. W., Jenkins, A., Jokat, W., Jordan, T., King, E. C., Kohler, J., Krabill, W., Riger-Kusk, M., Langley, K. A., Leitchenkov, G., Leuschen, C., Luyendyk, B. P., Matsuoka, K., Mouginot, J., Nitsche, F. O., Nogi, Y., Nost, O. A., Popov, S. V., Rignot, E., Rippin, D. M., Rivera, A., Roberts, J., Ross, N., Siegert, M. J., Smith, A. M., Steinhage, D., Studinger, M., Sun, B., Tinto, B. K., Welch, B. C., Wilson, D., Young, D. A., Xiangbin, C., and Zirizzotti, A.: Bedmap2: improved ice bed, surface and thickness datasets for Antarctica, The Cryosphere, 7, 375-393, https://doi.org/10.5194/tc-7-375-2013, 2013.

Greenbaum, J. S., Blankenship, D. D., Young, D. A., Richter, T. G., Roberts, J. L., Aitken, A. R. A., Legresy, B., Schroeder, D. M., Warner, R. C., van Ommen, T. D., and Siegert, M. J.: Ocean access to a cavity beneath Totten Glacier in East Antarctica, Nat. Geosci., 8, 294-298, https://doi.org/10.1038/ngeo2388, 2015.

Greene, C. A., Blankenship, D. D., Gwyther, D. E., Silvano, A., and van Wijk, E.: Wind causes Totten Ice Shelf melt and acceleration, Sci. Adv., 3, e1701681, https://doi.org/10.1126/sciadv.1701681, 2017.

Gulick, S. P. S., Shevenell, A. E., Montelli, A., Fernandez, R., Smith, C., Warny, S., Bohaty, S. M., Sjunneskog, C., Leventer, A., Frederick, B., and Blankenship, D. D.: Initiation and longterm instability of the East Antarctic Ice Sheet, Nature, 552, 225229, https://doi.org/10.1038/nature25026, 2017.

Gwyther, D. E., Galton-Fenzi, B. K., Hunter, J. R., and Roberts, J. L.: Simulated melt rates for the Totten and Dalton ice shelves, Ocean Sci., 10, 267-279, https://doi.org/10.5194/os-10267-2014, 2014.

Hirano, D., Mizobata, K., Sasaki, H., Murase, H., Tamura, T., and Aoki, S.: Poleward eddy-induced warm water transport across a shelf break off Totten Ice Shelf, East Antarctica, Commun. Earth Environ., 2, 1-8, https://doi.org/10.1038/s43247-021-00217-4, 2021.

Howat, I. M., Porter, C., Smith, B. E., Noh, M.-J., and Morin, P.: The Reference Elevation Model of Antarctica, The Cryosphere, 13, 665-674, https://doi.org/10.5194/tc-13-665-2019, 2019.

Huybrechts, P.: Glaciological modelling of the late Cenozoic East Antarctic Ice Sheet: stability or dynamism?, Geogr. Ann. A,
4, 221-238, https://doi.org/10.1080/04353676.1993.11880395, 1993.

Khazendar, A., Schodlok, M. P., Fenty, I., Ligtenberg, S. R. M., Rignot, E., and van den Broeke, M. R.: Observed thinning of Totten Glacier is linked to coastal polynya variability, Nat. Commun., 4, 2857, https://doi.org/10.1038/ncomms3857, 2013.

Li, X., Rignot, E., Morlighem, M., Mouginot, J., and Scheuchl, B.: Grounding line retreat of Totten Glacier, East Antarctica, 1996 to 2013, Geophys. Res. Lett., 42, 8049-8056, https://doi.org/10.1002/2015GL065701, 2015.

Masson-Delmotte, V., Schulz, M., Abe-Ouchi, A., Beer, J., Ganopolski, A., González Rouco, J. F., Jansen, E., Lambeck, K., Luterbacher, J., Naish, T., Osborn, T., Otto-Bliesner, B., Quinn, T., Ramesh, R., Rojas, M., Shao, X., and Timmermann, A.: Information from Paleoclimate Archives, in: Climate Change 2013: The Physical Science Basis. Contribution of Working Group I to the Fifth Assessment Report of the Intergovernmental Panel on Climate Change, edited by: Stocker, T. F., Qin, D., Plattner, G.K., Tignor, M., Allen, S. K., Boschung, J., Nauels, A., Xia, Y., Bex, V., and Midgley, P. M., Cambridge University Press, Cambridge, United Kingdom and New York, NY, USA, 2013.

Mohajerani, Y., Velicogna, I., and Rignot, E.: Mass Loss of Totten and Moscow University Glaciers, East Antarctica, Using Regionally Optimized GRACE Mascons, Geophys. Res. Lett., 45, 7010-7018, https://doi.org/10.1029/2018GL078173, 2018.

Nitsche, F. O., Porter, D., Williams, G., Cougnon, E. A., Fraser, A. D., Correia, R., and Guerrero, R.: Bathymetric control of warm ocean water access along the East Antarctic Margin, Geophys. Res. Lett., 44, 8936-8944, https://doi.org/10.1002/2017GL074433, 2017.

O’Brien, P. E., Post, A. L., Edwards, S., Martin, T., Caburlotto, A., Donda, F., Leitchenkov, G., Romeo, R., Duffy, M., Evangelinos, D., Holder, L., Leventer, A., López-Quirós, A., Opdyke, B. N., and Armand, L. K: Continental slope and rise geomorphology seaward of the Totten Glacier, East Antarctica $\left(112^{\circ} \mathrm{E}-122^{\circ} \mathrm{E}\right)$, Mar. Geol., 427, 106221, https://doi.org/10.1016/j.margeo.2020.106221, 2020.

Pritchard, H. D., Arthern, R. J., Vaughan, D. G., and Edwards, L. A.: Extensive dynamic thinning on the margins of the Greenland and Antarctic ice sheets, Nature, 461, 971-975, https://doi.org/10.1038/nature08471, 2009.

Pritchard, H. D., Ligtenberg, S. R. M., Fricker, H. A., Vaughan, D. G., van den Broeke, M. R., and Padman, L.: Antarctic ice-sheet loss driven by basal melting of ice shelves, Nature, 484, 502-505, https://doi.org/10.1038/nature10968, 2012.

Rignot, E., Mouginot, J., and Scheuchl, B.: Antarctic grounding line mapping from differential satellite radar interferometry, Geophys. Res. Lett., 38, L10504, https://doi.org/10.1029/2011GL047109, 2011.

Rignot, E., Jacobs, S., Mouginot, J., and Scheuchl, B.: Ice Shelf Melting Around Antarctica, Science, 341, 266-270, https://doi.org/10.1126/science.1235798, 2013.

Rignot, E., Mouginot, J., Scheuchl, B., van den Broeke, M., and Morlighem, M.: Four decades of Antarctic Ice Sheet mass balance from 1979-2017, P. Natl. Acad. Sci., 116, 1095-1103, https://doi.org/10.1073/pnas.1812883116, 2019.

Rintoul, S. R., Silvano, A., Pena-Molino, B., van Wijk, E., Rosenberg, M., Greenbaum, J. S., and Blankenship, D. D.: Ocean heat 
drives rapid basal melt of the Totten Ice Shelf, Sci. Adv., 2, 12, e1 601610, https://doi.org/10.1126/sciadv.1601610, 2016.

Roberts, J. L., Warner, R. C., Young, D., Wright, A., van Ommen, T. D., Blankenship, D. D., Siegert, M., Young, N. W., Tabacco, I. E., Forieri, A., Passerini, A., Zirizzotti, A., and Frezzotti, M.: Refined broad-scale sub-glacial morphology of Aurora Subglacial Basin, East Antarctica derived by an icedynamics-based interpolation scheme, The Cryosphere, 5, 551560, https://doi.org/10.5194/tc-5-551-2011, 2011.

Schlitzer, R.: Ocean Data View, available at: https://odv.awi.dem last access: 26 October 2021.

Silvano, A., Rintoul, S. R., and Herraiz-Borreguero, L.: Ocean-Ice Shelf Interaction in East Antarctica, Oceanography, 29, 130-143, 2016.

Silvano, A., Rintoul, S. R., Peña-Molino, B., and Williams, G. D.: Distribution of water masses and meltwater on the continental shelf near the Totten and Moscow University ice shelves, J. Geophys. Res.-Oceans, 122, 2050-2068, https://doi.org/10.1002/2016JC012115, 2017.

Silvano, A., Rintoul, S. R., Peña-Molino, B., Hobbs, W. R., van Wijk, E., Aoki, S., Tamura, T., and Williams, G. D.: Freshening by glacial meltwater enhances melting of ice shelves and reduces formation of Antarctic Bottom Water, Sci. Adv., 4, eaap9467, https://doi.org/10.1126/sciadv.aap9467, 2018.

Silvano, A., Rintoul, S. R., Kusahara, K., Peña-Molino, B., van Wijk, E., Gwyther, D. E., and Williams, G. D.: Seasonality of Warm Water Intrusions Onto the Continental Shelf Near the Totten Glacier, J. Geophys. Res.-Oceans, 124, 4272-4289, https://doi.org/10.1029/2018JC014634, 2019.

Silvano, A., Foppert, A., Rintoul, S. R., Holland, P. R., Tamura, T., Kimura, N., Castagno, P., Falco, P., Budillon, G., Haumann, F. A., Naveira Garabato, A. C., and Macdonald, A.: Recent recovery of Antarctic Bottom Water formation in the Ross Sea driven by climate anomalies, Nat. Geosci., 13, 780-786, https://doi.org/10.1038/s41561-020-00655-3, 2020.

Smith, J. A., Hillenbrand, C.-D., Kuhn, G., Larter, R. D., Graham, A. G. C., Ehrmann, W., Moreton, S. G., and Forwick, M.: Deglacial history of the West Antarctic Ice Sheet in the western Amundsen Sea Embayment, Quaternary Sci. Rev., 30, 488-505, https://doi.org/10.1016/j.quascirev.2010.11.020, 2011.
Tamura, T., Ohshima, K. I., and Nihashi, S.: Mapping of sea ice production for Antarctic coastal polynyas, Geophys. Res. Lett., 35, L07606, https://doi.org/10.1029/2007GL032903, 2008.

Thomas, G., Purkey, S. G., Roemmich, D., Foppert, A., Rintoul, S. R.: Spatial variability of Antarctic bottom water in the Australian Antarctic Basin from 2018-2020 captured by Deep Argo, Geophys. Res. Lett., 47, e2020GL089467, https://doi.org/10.1029/2020GL089467, 2020.

Thompson, A. F., Stewart, A. L., Spence, P., and Heywood, K. J.: The Antarctic Slope Current in a Changing Climate, Rev. Geophys., 56, 741-770, https://doi.org/10.1029/2018RG000624, 2018.

Van Graas, S. and Dirita, V.: RV Investigator Voyage IN2017_V01 CTD Data, available at: https://marlin.csiro.au/geonetwork/ srv/api/records/b8b1a0f1-53cf-4ae8-818d-ef3eaaeb3bba/ formatters/xml, last access: 26 October 2021.

Wakatsuchi, M., Ohshima, K. I., Hishida, M., and Naganobu, M.: Observations of a street of cyclonic eddies in the Indian Ocean sector of the Antarctic Divergence, J. Geophys. Res., 99, 20417 20426, https://doi.org/10.1029/94JC01478, 1994.

Williams, G. D., Meijers, A. J. S., Poole, A., Mathiot, P., Tamura, T., and Klocker, A.: Late winter oceanography off the Sabrina and BANZARE coast $\left(117-128^{\circ} \mathrm{E}\right)$, East Antarctica, Deep-Sea Res. Pt. II, 58, 1194-1210, https://doi.org/10.1016/j.dsr2.2010.10.035, 2011.

Wright A. P., Young, D. A., Roberts, J. L., Schroeder, D. M., Bamber, J. L., Dowdeswell, J. A., Young, N. W., Le Brocq, A. M., Warner, R. C., Payne, A. J., Blankenship, D. D., van Ommen, T. D., and Siegert, M. J.: Evidence of a hydrological connection between the ice divide and ice sheet margin in the Aurora Subglacial Basin, East Antarctica, J. Geophys. Res., 117, F01033, https://doi.org/10.1029/2011JF002066, 2012.

Young, D. A., Wright, A. P., Roberts, J. L., Warner, R. C., Young, N. W., Greenbaum, J. S., Schroeder, D. M., Holt, J. W., Sugden, D. E., Blankenship, D. D., Van Ommen, T. D., and Seigert, M. J.: A dynamic early East Antarctic Ice Sheet suggested by ice covered fjord landscapes, Nature, 474, 72-75, https://doi.org/10.1038/nature10114, 2011. 